\title{
The Giving Reasons Requirement
}

\author{
Martin Shapiro ${ }^{\dagger}$
}

Article 190 of the EEC Treaty provides that:

Regulations, directives and decisions of the Council and of the Commission shall state the reasons on which they are based...

Giving reasons might appear to be a rather simple and commonsense requirement. In reality it is densely packed with past legal and constitutional experience and replete with potential for development, particularly for development of a pervasive and deeply intrusive style of judicial review of administrative and legislative decisionmaking.

This Article will first consider the various streams of past experience and then examine future implications. Much of our attention will focus on the American experience. In both evaluating U.S. experience and speculating on the potential for further growth in the European Community ("EC" or "Community") that this experience might imply, many European readers will say to themselves, "This may work perhaps for American or for common law judges, but never for Continental or Civil Law judges." Let me ask now that my reader willingly suspend disbelief in the comparability of American and continental judicial mind-sets until fairly late in this piece, where we can begin to address the actual European experience. Beyond this suspension of disbelief, perhaps it is enough to note post-World War II developments in European judicial review. Constitutional courts in Germany, Italy, and even in that seemingly unbreachable bastion of judicial self-restraint, France, as well as the European Court of Human Rights, the European Court of Justice ("ECJ"), and British courts reviewing administrative decisions have reached levels of judicial activism quite American in style. A plausible premise exists for European judiciaries to adopt more and more of the American style.

$\dagger$ James W. and Isabel Coffroth Professor of Law, University of California, Berkeley. 


\section{Giving Reasons and Reasonableness: A Comparative Law APPROACH}

\section{A. Giving Reasons and Administrative Discretion}

The American welfare and regulatory state has grown largely through the delegation of legislative powers to administrative agencies that generate vast bodies of regulations, rules and decisions under the authority of statutes. The authorizing statutes themselves often are worded so generally as to place few constraints on administrative lawmakers. If the statutes are more detailed, they usually establish a pattern of generally stated aspirations combined with complex, yet incomplete and potentially conflicting, specific commands that yield as much administrative discretion as do New Deal-style "standardless" delegations. Moreover, the welfare state requires millions of small decisions tailored to the individual needs of particular claimants. Decisions such as when a single parent on welfare ought to be required to work, as opposed to being urged to go back to school, are not easily encapsulated in statutory language or even detailed agency regulations. Finally, the same welfare state requires that government engage in myriad management decisions about resource allocation, decisions that experience has shown are best left to the sort of management discretion that exists in large private enterprises.

Rulemaking discretion, the discretion to treat unlike cases in unlike ways, and resource management discretion are, therefore, not only inevitable but welcomed features of contemporary administration. However, since the 1960 s there has been increasing pressure to constrain that discretion. All sorts of devices for attenuating the potential evils of administrative discretion have been suggested. Many ideas involve improvements on the legislative side, through either better statute drafting or more active and informed legislative oversight. Other proposals involve improving the organization, staffing, and operations of the agencies themselves.

Giving reasons requirements are a form of internal improvement for administrators. A decisionmaker required to give reasons will be more likely to weigh pros and cons carefully before reaching a decision than will a decisionmaker able to proceed by simple fiat. In another aspect, giving reasons is a device for enhancing democratic influences on administration by making government more transparent. Such requirements are often closely brigaded, as they are in the American Administrative Procedures Act ("APA"), with 
requirements of notice of pending government actions, public consultation, and publication of final decisions. ${ }^{1}$

In these aspects, giving reasons requirements are not "giving reasons to judges" requirements but "giving reasons to the public" requirements. Administrators must inform the citizens of what they are doing and why. Such requirements are a mild self-enforcing mechanism for controlling discretion. The reason-giving administrator is likely to make more reasonable decisions than he or she otherwise might and is more subject to general public surveillance.

\section{B. Giving Reasons and Judicial Review of Administrative Action}

In another respect, however, giving reasons has been deeply entangled with judicial review. If administrative discretion is inevitable and desirable, then one obvious mode of denaturing discretion of its poisons is to set judges to watch administrators.

Giving reasons is one of the mildest forms of judicial supervision of administrative discretion. Its deepest roots are in political theory. As Carl Friedrich noted long before the recent focus on reason giving, in the Western tradition, the very concept of political authority, or indeed any kind of authority, implies the capacity to give reasons. ${ }^{2}$ When we impute authority, as opposed to merely acknowledging power, we are asserting our belief that the persons or entities making statements or rendering decisions could, if called upon, give good reasons for what they have said or done. It is natural, then, to ask administrative authorities actually to give reasons and to view such a request as the mildest of all constraints on administrative discretion. Such a request is not a limitation on the scope or substance of the discretion but merely a test of the authority of the administrator to wield discretion. Administrators may still arrive at whatever decisions they think best; they must merely give reasons for the decision at which they did arrive.

Precisely because giving reasons constitutes the mildest form of judicial intrusion, this constraint on discretion has been particularly popular in systems of cabinet government, where legislative and executive power are theoretically merged in a sovereign parliament. In such systems, judicial review of the executive is highly suspect as an invasion of parliamentary sovereignty. At the same time American conservatives sought to rein in the New Deal by the

1 Administrative Procedure Act, 5 USC $\S 551-706$ (1988).

2 Carl J. Friedrich, "Authority, Reason, and Discretion," in Carl J. Friedrich, ed, Authority 28 (Harvard Univ Press, 1958). 
judicially announced "non-delegation" doctrine in such cases as Carter v Carter Coal Co. ${ }^{3}$ and A.L.A. Schechter Poultry Corp. $v$ United States, ${ }^{4}$ British conservatives sought to constrain their growing administrative state by pushing giving reasons requirements. They urged that Parliamentary statutes giving ministers standardless discretion to act as they thought best should not foreclose judicial review and should require "speaking orders"-that is, government decisions containing reasons as well as conclusions and commands.

1. The growth of giving reasons into a "record" requirement.

The evolution of the giving reasons requirement in U.S. administrative law dramatically illustrates its potential for growth. Giving reasons has served as a judicial constraint on administrative discretion, even when that discretion appears to be subject only to the broadest and vaguest statutory standards. Most fundamentally, if there is no record of agency deliberation, an administrative agency wielding its discretion is impervious to judicial review. If the court sees only the agency's final decision, the judge has a difficult time raising even jurisdictional questions. In the absence of any rationale at all, for example, horses may fall under the jurisdiction of the agency administering the chicken statute. In some way or another, after all, horses may impinge upon chickens in the barnyard.

A giving reasons requirement generates a record. And once a judge has a record, anything is possible. At their most modestly restrained, British judges even in the 1950s could bring themselves to quash an administrative decision when it showed an "error of law on the face of the record." Could it be, after all, that the requirement to give reasons was a purely formal one-that so long as the administrator gave some reason, no matter how bad or how wrong, he or she was home free? Giving reasons, of course, not only creates a record consisting literally of the reasons given, but of the statutes and/or regulations that those reasons elaborate. Thus, the giving reasons requirement opens the door to rival statutory interpretation by court and agency.

Where statutes are generally or vaguely worded to grant broad administrative discretion, administrators can easily avoid such

\footnotetext{
${ }^{3} 298$ US 238 (1936).

- 295 US 495 (1935).

- Carol Harlow and Richard Rawlings, Law and Administration 100-101 (Weidenfeld \& Nicolson, 1984).
} 
manifest errors of law, by adopting boilerplate statements of reasons that do nothing more than state the statutory language as a "whereas" and decisions as a "therefore." This tactic becomes less successful the more complex and specific the statute, and reviewing courts continuously address the question of how accepting they should be of such boilerplate.

Moreover, most administrative implementations of statutory norms involve applications to fact situations sufficiently complex and sufficiently in dispute that a giving reasons requirement inevitably imposes some pressure on the administrator to offer at least summary findings of fact. Giving reasons of fact renders administrators much less vulnerable to judicial review than giving reasons of law. Courts must respond to manifest errors of law because their most fundamental duty is to uphold law. Their access to and expertise in the law is as good as or superior to that of the agencies. After all, even extrinsic aids to statutory interpretation, like legislative history, are as available to judges as administrators.

On the other hand, administrators enjoy superior expertise and access with respect to facts. Judges have no special duty to facts as they do to the law. Moreover, under some conditions, and particularly in the area of individual welfare claims, the factual dimension of giving reasons is just as open to the boilerplate tactic as is the legal dimension. Administrators test various factual reasons on the courts. Those receiving judicial approval become a catalogue of fixed formulae from which the one that best fits the individual or situation before the decisionmaker, and most nearly matches the decision he or she intends to make, can be plucked and tendered. Here again, courts must decide whether they find such pre-prepared reasons palatable.

Nevertheless, if giving reasons engenders giving facts, the giving reasons requirement at the very minimum turns into an embryonic "record" requirement. Giving reasons allows judges to run through, replay, or reconstruct the decisionmaking process that led to the policy decision under review. I have argued elsewhere that retracing the administrators' decisionmaking process is the essence of all judicial review of administration. ${ }^{6}$ Surely the more the judge can replay the administrator's game, the more tempted he or she will be to do so.

Giving reasons requirements then have this "record" potential for moving beyond the mildest level of judicial review to a level at 1968).

- Martin Shapiro, The Supreme Court and Administrative Agencies (The Free Press, 
which judges match their own policy analyses against those of the agencies. But that is not the only such potential of giving reasons requirements.

2. The evolution of giving reasons into a means of substantive judicial review.

It may well be that, initially, giving reasons requirements were less about creating a mild form of judicial review than they were about creating an internal check on administrative discretion. As we have noted, any decisionmaker under an obligation to give reasons may be less prone to arbitrary, capricious, self-interested, or otherwise unfair judgment than one under no such obligation. Perhaps establishing an enforcement mechanism for the giving reasons requirement itself, not creating an entering wedge for judicial review of agency procedures or decisions, provided the original purpose behind judicial enforcement of the reason-giving requirement. The judge may have been perceived as a mere enforcement agent for the requirement, and the requirement itself may have been thought as improving the intrinsic performance of administration, not subjecting it to outside supervision. If this was the initial intention, in the United States at least, the outcome has often been quite the contrary.

The most prominent giving reasons requirement in an American statute is the Administrative Procedures Act requirement that informal rules be accompanied by a "concise general statement of their basis and purpose." The statute also provides an explicit judicial review standard. Informal rules may not be unlawful or "arbitrary and capricious," nor may they be an "abuse of [agency] discretion.",

The relation of judicial review to giving reasons shifts dramatically depending upon the context. In the English system, for instance, judicial review may be seen as essentially a means of enforcing the giving reasons requirement. The judge merely acts as a policeman, reviewing to ensure that the administrator obeys the statutory command to give reasons. When combined with a substantive review standard, however, means and ends dramatically reverse. Instead of the court reviewing to ensure that the agency gives reasons, the agency must give reasons to ensure that the court can review. Judges begin to say to agencies, "You must give us enough reasons to enable us to tell whether you have acted rea-

75 USC $\S 553(\mathrm{c})(1988)$.

Id. 
sonably or arbitrarily and capriciously." As this dynamic unfolds, giving reasons moves from a mild and self-enforcing restraint on administrative discretion to a quite severe, judicially enforced set of procedural and substantive restraints-or at least so it has in the American context.

This story has been told at length elsewhere, and only a brief summary should suffice here. ${ }^{\theta}$ The APA roughly distinguishes two types of administrative agency rulemaking. Formal rules are to be made by rather rigid court-like procedures, with a complete record culminating in findings of fact and law supporting the rule announced. Informal rulemaking requires that the agency give notice of its intention to make a rule, then accept comments by the public, and ultimately publish its rule accompanied by a concise and general statement of its basis and purpose. As we have already noted, this latter requirement is the giving reasons component. The APA makes no mention of a record requirement for informal rulemaking. Juxtaposing the provisions on formal and informal rules makes clear that the central difference intended between them was that the former was to have formal findings based on a formal record and the latter was not.

The Act was passed in 1946 and, until at least the mid-1960s, that distinction was maintained. By the 1980s, the federal courts had invented, supposedly by statutory interpretation, the concept of the rulemaking record. Informal rules had to be accompanied by records and findings even more detailed and elaborate than had been initially envisioned for formal rulemaking. The courts performed this feat largely by elaborating the giving reasons requirement along three dimensions.

First, the courts converted the purpose of giving reasons from informing the public to allowing judicial review to determine whether a rule was either arbitrary and capricious or an abuse of discretion. The courts turned the notion of "arbitrary and capricious" on its head by arguing that a rule was not arbitrary and capricious only when it was well reasoned and well supported by facts. Although initially only formal rules required grounding in "substantial evidence in the record as a whole," eventually courts expanded the concise and general statement of basis and purpose accompanying informal rules into an enormously elaborate justification of the rule the agency had adopted. Only then could the

s Martin Shapiro, Who Guards the Guardians? (Univ of Georgia Press, 1988). 
judges determine whether the rule was properly reasoned rather than arbitrary.

Second, the courts expanded the APA's notice and comment provisions into the dialogue requirement. Requiring an agency to invite comment would mean little if the agency did not listen seriously to those comments it received. After all, courts had a duty to enforce the APA. The only way judges could know whether the agencies were listening seriously was by requiring the agencies to reply to each and every argument offered by interested parties. Giving reasons thus became an agency obligation to respond to each and every comment made with regard to a proposed rule.

The third dimension is a subtle variant of the second. By the 1970 s, federal courts were saying that agencies had to respond to all issues raised by participating parties in the informal rulemaking proceedings. By the 1980 s, they were saying that agencies had to respond to all issues, not just those issues raised by the parties. The agencies now not only were required to engage in a serious dialogue and prove it by giving reasons about each point raised by the participants, but they were also required to make synoptic decisions-that is, to set clear policy priorities, consider all possible alternative rules for achieving those priorities, gather all relevant facts, and adopt the rule that had the very best chance of achieving the chosen priorities in light of the facts. In this context, the obligation to give reasons becomes the obligation to defend synoptically a synoptic decision-to offer every reason needed to resolve every issue of fact, value, and choice among alternative policies that could arise in making the optimal rule.

The movement from the second to the third dimension was hardly noticed. As environmental, health, and safety legislation raised the monetary stakes in rulemaking higher and higher, regulated industries and their "public interest" opponents poured more and more resources into raising ever more issues at rulemaking hearings. They raised every issue that they could imagine. Therefore, the practical difference between responding to every point made by the parties and responding to every point imaginable was not very great, though implications for judicial control were considerable. Now agencies had to prove to judges that the agency reasons were better than any other reasons. Giving reasons had changed from "You can adopt any rule you please as long as you give reasons" to "You must adopt the best-reasoned rule."

Giving reasons had been converted from a very mild, essentially procedural, requirement into a very draconian, substantive one. In a certain sense, such a conversion was both inevitable and 
peculiarly easy. Once giving reasons reaches far enough to require the agency to give a fairly full account of the factual basis for its decision, judges are in a position to second-guess administrators. The only way to cut judges off from such second-guessing is to cut them off from the facts. Judges then have no choice but to approve what administrators have done as long as it is based on any seemingly articulate statement of reasons. For without the facts, how can one tell whether the reasons make any sense-unless, of course, the administrators have made a manifest error of law on the face of their reasons? Moreover, if facts are available, how can a judge possibly assess the adequacy of the reasons given other than to examine those facts and see whether he reaches roughly the same conclusion that the agency has reached?

In reviewing the facts, judges will accept plausible reasons only for those outcomes that are reasonable. If on the facts the judges conclude that a given outcome is simply not defensible, they are not going to accept any set of reasons backing it, no matter how superficially plausible those reasons may be. Once a judge with a duty to enforce a reasons requirement has access to a factual record, even a rudimentary one, a giving reasons requirement ceases to be purely procedural. The requirement then engenders some degree of substantive judicial review of the lawmaking discretion of others. Substantive review is, of course, a polite way of saying that, to some degree, judges substitute their own policy guesses for the policy guesses of others.

This inevitable shift of reason-giving from procedure to substance in the presence of facts is smoothed, however, by the procedural veneer of reasons-giving. Judges know that substantive review-that is, saying that a rule is unlawful just because it is poor-constitutes a substitution of their policy views for the views of others. The "others," moreover, are legislatures or bureaucracies that enjoy policy-making resources and democratic authorization far superior to those of the courts. Thus, when judges engage in substantive review, they tend to seek some way to mask their resource and democracy deficits.

Giving reasons review is an ideal cover. First, it is cast in the form of procedural, rather than substantive, review. Judges will tell the agency, "It is not that the rule is necessarily unlawful, but rather that you have missed a procedural step. You have not given adequate reasons." The emphasis is, of course, on the "given," not on the "adequate" - that is, on the failure to perform a required action, not on the badness of the action performed. Secondly, and more importantly, giving reasons review provides judges with a 
suspensive, although very powerful, policy veto. The judge says, "I reject your rule because you have not offered good reasons for it. Resubmit the rule with a better set of reasons. Of course, I reserve the right to reject your rule again if the second set of reasons are no better than the first." In this situation, most prudent agencies will recognize the need to change the substance of their rule rather than simply change the rhetoric of the reasons. The agency's change in the rule, however, will be seen as "voluntary." Certainly in the 1980s, U.S. appellate courts, and particularly the D.C. Circuit, performed extensive substantive review, routinely striking down rules that they considered less than the best policy. However, since most rules were sent back as "inadequately reasoned," it is still possible to argue that nearly all American judicial review of rulemaking has remained procedural.

In summary, then, the American experience at least argues that "giving reasons" has a strong tendency for growth. It begins as a mild and self-enforcing restraint on administrative policy discretion. Anyone who must give reasons to anyone else is likely to be more circumspect than he or she otherwise would be, and anyone who has to give reasons to the public is more likely to be responsive to it than otherwise. When courts enforce giving reasons, however, the audience for the reasons shifts from the public to the judges. For the judges to evaluate the reasons given, they must have enough information to rule on the adequacy of those reasons. The judges are not there merely to bless false facades of reasons.

Considering interest group participation in administrative decisionmaking, the audience for reasons further multiplies. Reasons must not only be given in general, and to the public, and to the judges, but to the participants. Moreover, the reasons the participants want are the reasons for the rejection or acceptance of each of their specific claims. All of this finally may lead "giving reasons" to become a judicially enforced demand that the rulemaker prove that it has made the very best decision possible within its range of discretion. An administrator who must choose the "best" rule, of course, has no discretion. He or she has no choice but to choose the best rule according to the reviewing court. Thus, a requirement that begins as a mild, generalized restraint on discretion may become the substitution of judicial discretion for administrative discretion.

This potential for growth is, nonetheless, just that-a potential. Such developments may not occur, or may take place only partially. And even if they go quite far, judges always have discretion over their own decisions. Individually, judges may be more or 
less easily satisfied by the reasons administrators give. Many factors no doubt impinge on the propensity of a judge at any particular time and place to push giving reasons into substantive judicial review. American judges may already be retreating from their stance of the 1980s. Yet offering, or imagining, the extreme extension of a legal doctrine sheds light on its current condition.

\section{Reasonableness and Constitutionality}

Given a great deal more space, I think I could show that, from a reviewing court's perspective, in American constitutional law and all other constitutional law, the ultimate test of a statute or other government action is reasonableness. What is reasonable is constitutional. What is unreasonable is not. For the moment let me make a lesser and more quickly supported claim. In American constitutional law, where it can be demonstrated that a statute infringes on a right specifically guaranteed by the Constitution or that the exercise of government power by a particular governmental entity breaches the boundaries established by the federalism and separation of powers provisions of the Constitution, a sufficiently persuasive demonstration of the reasonableness of an infringement or breach may save its constitutionality.

Instead of exhaustive proof of even this narrower claim, let me provide a few well-known examples. The best known, of course, is the dreaded substantive economic due process of pre-New Deal days. Under that doctrine, when a statute threatened an owner's free enjoyment of property, the Court examined whether that limitation was reasonable under laissez-faire economic theory. From about 1890 to 1937 , the Court compiled a long record of striking down some state economic regulations and upholding others. While many of the opinions invalidating regulation were phrased as if property rights were absolute, the whole pattern of opinions clearly shows that the Court judged constitutionality on the basis of which state manipulations of the free market could and could not be justified in terms of economic efficiency or net welfare gain and loss. Even when the New Deal Court announced it would presume the constitutionality of economic legislation, the Court carefully preserved the doctrinal position that ultimately the test of an economic regulation under the due process clause was reasonableness. ${ }^{10}$

10 Martin Shapiro, "The Supreme Court's 'Return' to Economic Regulation," in 1 Studies in American Political Development 91 (Yale Univ Press, 1986). 
The announced demise of substantive economic due process has been followed by the rise of substantive equal protection, economic and otherwise, for a wide assortment of classes of persons claiming a disadvantaged status in American society. This jurisprudence may now be in the process of erosion or at least rapid transformation, so that only a careful chronological description could do it justice. For purposes of illustrating my point about reasonableness, however, let me instead offer a static description of the high point of this jurisprudence. When a state appears to threaten the right to equal protection by employing a "suspect classification," such as race, or by invading a constitutionally guaranteed right, such as the right to vote, then the state action is constitutionally justified only if it serves a "compelling state interest" and is "narrowly drawn" to serve that interest by the means least intrusive on constitutional rights. A statute employing a semi-suspect classification, such as gender, is constitutional if the state's interests are "important" or "substantial" and the means chosen are "substantially" or "reasonably" related to the achievement of those interests. Where mere property rights are involved, the government act is subject only to the conventional, post-1937 "rationality" test.

This is the famous two-tiered-become-three-tiered equal protection test which recently may have become a five-tiered test. There now may be a tier between minimum rationality and the intermediate level. At this new tier, courts apply the conventional, post-1937 rationality test without the post-1937 judicial convention of always upholding any statute subjected to the test. This test, called the rationality "with teeth" tier, sometimes becomes the rationality "with shark-like teeth" tier.

Yet another tier may lie between the intermediate tier and the highest tier. At this fifth tier, statutes are constitutional if they do not "unduly burden" constitutionally protected rights, whether or not they are the least intrusive means of achieving the state's interests. These five tiers seem to apply not only to the equal protection clause but to the due process clauses as well.

If you find all this very tiresome, as have several of the justices, you might describe it somewhat differently. The Court balances state interests against a statute's infringements on constitutional rights. In doing so, the Court bears in mind that if the state could effectively pursue its interests in a way that minimized damage to constitutional rights (or at least was less damaging than the statute at issue), the state ought to use that way. In short, the judges imagine how, if they were legislators, they would draft the 
statute to balance state interests and constitutional rights. If the statute is one the judges would have drafted and voted for as legislators, it is one whose constitutionality they will vote for as judges. Or, if you prefer a more modest construction, if the statute is one that reasonable legislators dedicated to protecting constitutional rights would have enacted, then it is constitutional. Even more concisely, if the statutory goals are legitimate, and the statute avoids all reasonably avoidable intrusions on constitutional rights, and it makes a reasonable accommodation between its ends and means on the one hand and constitutional rights on the other when some invasion of rights is inevitable, then it is constitutional. Shorter yet, if the Court thinks the statute is reasonable, it is constitutional.

The reasonableness or balancing approach which we have just described is even more evident under the First Amendment than under the due process and equal protection clauses. Unlike the vague wording of those clauses, the First Amendment seems very clear: "Congress shall make no law . . . abridging the freedom of speech or of the press." Yet, from its earliest free speech decisions, the Supreme Court has consistently held that the government may abridge freedom of speech when it can allege a sufficiently strong interest in doing so. The Court itself ultimately must balance the extent of the damage to the speech right against the weight of the government interest served by the infringement on speech. There is the usual restrictive "least means" proviso. If the interests could have been equally served by a less burdensome government action, then the government action is unconstitutional. Among the interests weighed against speech are national security, the physical security of persons, the fairness of elections, affront to the community's moral sense, the prevention of fraud, and the invasion of privacy. Even when such interests on balance may not justify total repression of speech, they may constitutionally justify "reasonable time, place, and manner" regulations. The First Amendment really reads "Congress shall make no law abridging the freedom of speech that the Supreme Court finds on balance to be unreasonable."11

This reasonableness analysis emerges yet again with respect to the division of powers aspects of the Constitution. The clearest example for scholars of the European Community is the American "negative" or "dormant" Commerce Clause. Under the Commerce Clause, where Congress has not acted to regulate, the states may

$"$ Martin Shapiro, Freedom of Speech: The Supreme Court and Judicial Review ch 3 (Prentice Hall, 1966). 
regulate interstate commerce unless their regulation creates interference. Unlike the EC treaties, the Commerce Clause is not a free movement of goods clause. It simply specifies that Congress may regulate interstate commerce. The Supreme Court might have ruled from the beginning that the clause gave Congress an exclusive power over commerce. The Court has never done so. Nor has it ever successfully drawn boundaries between interstate and intrastate commerce. The Court has declared that the states have a concurrent power to regulate interstate commerce so long as state regulations do not conflict with federal ones or Congress has not acted to preempt or occupy the field. The Court has also held that non-interstate commerce subject to state regulation may be regulated by Congress so long as that commerce has some relation to interstate commerce. Finally, the Court has held that, even when Congress has been silent, state regulation of intrastate commerce that burdens interstate commerce violates the Commerce Clause. This is the negative or dormant Commerce Clause.

The jurisprudence of the negative Commerce Clause will strike familiar chords for those involved with Community free movement jurisprudence. Notions of proportionality; margin of appreciation; legitimate state interests in health, safety and environment; discrimination; and tariff analogies play out in roughly the same way in European and American law. ${ }^{12}$ An extremely rich and varied legacy of American cases all come down to a bottom-line technique: the Court decides whether, in light of the justices' understanding of free trade, the state regulation constitutes a reasonable accommodation of legitimate local interests with the constitutional goal of creating and maintaining a national free trade zone. Of course, the justices' understanding of local interests, free trade, and economic theory have changed over time. However, the ultimate issue has always been the reasonableness of the state commerce regulation under whatever articulated or unarticulated economic theories the justices entertained at any given time.

One could go on multiplying examples. I hope these will suffice. I hope also that it will be clear, without a lot of philosophic discourse (of which I am incapable), that there is a relationship between reasonableness and giving reasons. An action is reasonable if reasons for it can be given. But something more is involved. The reasons given have to count as good reasons. The famous parental

12 Terrance Sandalow and Eric Stein, eds, Courts and Free Markets: Perspectives from the United States and Europe ch 3 (Clarendon Press, 1982). 
reason of last resort, "Because I say so," does not render the parental command reasonable to the child or to anyone else.

\section{Parallels Between Administrative and Constitutional Giving Reasons}

We may, therefore, see the American constitutional judicial review standard of reasonableness as a massive requirement to give good reasons. This requirement applies to legislatures as well as administrators, at least where their actions impinge on constitutional rights or transgress constitutionally established divisions of power. In its various manifestations, the constitutional requirement of reasonableness parallels a wide range of giving reasons requirements encountered in administrative law. One must note, however, that the constitutional giving reasons requirement is never as purely procedural as the administrative one may be, at least where an act of the legislature is at issue. An American court never declares a statute unconstitutional simply because the legislature has not given reasons. Legislatures are not seen as subject to a formal giving reasons requirement. Nor does an American court ever uphold the constitutionality of a statute simply because the legislature has offered reasons. The constitutional reasonableness requirement is a substantive giving reasons requirement. Instead of asking the procedural questions "Did the decisionmaker give reasons?" the constitutional requirement asks the substantive question, "Can good reasons be given for this statute?"

In other words, the American constitutional giving reasons requirement does not increase the transparency or democratic responsibility of the legislative process by ensuring that the people be told why and how a particular legislative decision was made. ${ }^{13}$ The issue is what reasons can be given, even if those reasons are entirely post-hoc and invented by the litigators defending the constitutionality of the statute. However, certain exceptions exist in which the legislature's actual justification for the statute becomes more important than the question of substantive reasonableness. For instance, a law for which good reasons can be given still may be unconstitutional if the intent behind the law violates the Constitution. Thus, where a legislature subjectively intended to dis-

13 The constitutional requirement of due process when applied to the decisions of political executives rather than legislatures may entail some kind of transparency requirement which might be satisfied by giving reasons or by evidence that the decisionmaker had in fact considered those things he was required to consider. See Citizens to Preserve Overton Park Inc. $v$ Volpe, 401 US 402 (1971). 
criminate against a racial minority, the statute is unconstitutional no matter how many good reasons can be offered. Distinctions that are easy in theory, however, often disappear in practice. In the absence of the smoking gun of language proclaiming discriminatory intent in a legislative or administrative history, whether or not government action is found to be tainted by a constitutionally forbidden intention often becomes a question of how many good reasons can be offered in its behalf.

The "reasonableness with teeth" equal protection standard described earlier comes very close to the "not arbitrary and capricious" standard of reason-giving in administrative law. Instead of asking whether the government action is the best that can be imagined, or even if it is a correct or good action, the court only asks whether a reasonable person could have had a legitimate reason for doing what was done. Absent such a reason, the action is (in administrative law terms) arbitrary and capricious or (in constitutional law terms) beyond the presumption of reasonableness.

When we arrive at the middle tier of quasi-suspect classifications, constitutional reason-giving parallels the demand for "reasoned decisionmaking" that the D.C. Circuit invented as a replacement for the arbitrary and capricious standard for administrative rulemaking. This intermediate level of scrutiny applies to gender classifications. ${ }^{14}$ In gender cases, the Court has accepted differential treatment based on gender where good reasons could be offered for that treatment or, as the Court often says, the gender classification is reasonably related to an important government interest. And like the D.C. Circuit in informal rulemaking cases, the Supreme Court essentially reworks the policymaking process the legislature went through in the first place. The Court will uphold the initial decision if the reasons appear sufficient to justify it, even if the Court does not regard the outcome as ideal.

\footnotetext{
14 This "intermediate scrutiny" category for equal protection first arose because of some of the differences between racial and gender discrimination. Racial discriminations required "strict scrutiny" by the Court, both because few racial classifications could be appropriate to the légitimate ends of government and because after the Court ended "separate but equal," many southern governments sought in bad faith to evade desegregation. Under these circumstances, the Court could hardly accept at face value reasons given for continued racial discrimination.

In contrast to race, gender classifications might be socially useful in many instances, and the level of gender animus in the United States has hardly been comparable to the racial animus that inspired Southerners' resistance to desegregation. In light of traditional social attitudes toward women, the Court demanded quite good reasons to justify gender classifications, but it did not treat them with the absolute suspicion with which it greeted racial classifications.
} 
A test between intermediate level scrutiny and suspect classification-fundamental rights-strict scrutiny would give the initial decisionmaker less benefit of the doubt. Such a test would correspond to the D.C. Circuit's demand for "reasoned elaboration" in rulemaking, in which even a rule backed by good reasons could fail if the court found that an even better rule might have been made.

The Supreme Court's constitutional demands with regard to strict scrutiny or First Amendment balancing tests parallel the demand for synoptic rulemaking in administrative law-that is, the demand that the rulemaking agency respond to all issues, not simply all issues raised by the parties. The "least means" or "narrowly tailored" test in constitutional law is comparable to this "respond to all issues" demand. Once the Court has accepted some state interest as justifying some infringement on a fundamental right, the justices themselves engage in a legislative run-through. If they can imagine any statute that might achieve the state's interest at less cost to fundamental rights than the statute at issue, that statute is unconstitutional. To put the matter slightly differently, the state has the burden of showing that the statute is as perfect as it can be, that the state has considered all other alternatives and has good reasons for rejecting each of them.

These constitutional cases, however, give the Supreme Court somewhat less of an opportunity to test its synoptic skills than the informal rule cases give the D.C. Circuit. The judicially forced expansion of the rulemaking record to include not only every fact, but every hint, speculation, and invitation to further research that the fertile minds of lawyers and experts can call forth, allows reviewing courts either to imagine a better rule themselves or fault the rulemaker for not showing conclusively that no better rule was possible. In the constitutional cases, the factual record and expert speculation is not usually so voluminous. The Court's raw materials are not the huge mass that a dozen interest groups and large corporations and their attendant lawyers and experts have been able to pour into a rulemaking record, but the lesser mass that the lawyers for two parties have managed to pour into their briefs. The justices have less material on which to exercise their legislative imaginations and thus are somewhat less likely to fault the statutemaker for not having imagined every last possible alternative. Nonetheless, the restrictive aspect of strict scrutiny requires that, at least post hoc, the lawyers for the state provide good reasons why each of the other alternatives was not adopted, as well as good reasons in defense of the one that was. 
There is a crucial difference between these American constitutional and administrative law giving reasons requirements. The administrative law requirements began as procedural checks and turned into substantive ones. The constitutional ones, with some major exceptions, were substantive checks that have not turned into procedural ones. Courts interpret the APA provisions to demand that the agency employ a process of reasoned elaboration in deciding on its rules. Post hoc reasons offered by government counsel in the course of rule-testing litigation do not meet that demand. The question is not "Can reasons be given?" but rather "Were reasons given?" When a reviewing court quashes a rule because good reasons were not given, the court will frequently be signalling that it really thinks the rule is a bad one. Even when its objections are really substantive, however, the form the court adopts is procedural. The agency is denied its rule not because the rule is bad, but because the agency did not give reasons for it. In theory at least, the agency might succeed the second time around if it ran another rulemaking process full of reasons and came back to court with the same rule. Thus, the courts both refuse post hoc reasons and soften their substantive review by packaging their decision as a procedural and, therefore, only suspensive veto.

In determining whether a statute is constitutional under a balancing standard, the questions are typically substantive, not procedural: "Can reasons be given?" rather than "Were reasons given?" Post hoc reasons given by litigating lawyers are accepted. But for that very reason, the veto is substantive and complete, rather than procedural and suspensive. If reasons cannot be given that satisfy the least means test, the statute is unconstitutional, period. It may be true in theory that where legislation has failed an intent standard, a legislature might try the same law again accompanied by a new legislative history full of good reasons and devoid of professed discriminatory intent. Yet, it is hard to imagine many circumstances in which the theory could be turned into successful practice.

Finally, it should be noted that, except perhaps for some instances falling under the purest procedural due process applications of the Fourteenth Amendment, courts exercising constitutional review do not resort to the "response to all issues raised by all parties" version of the giving reasons requirement. Statutes are not struck down because the legislative history reveals that points raised during hearings and debates were not answered. While courts hold that the APA places a "dialogue" requirement on 
rulemaking agencies, courts also do not recognize that the Constitution imposes one on legislatures.

\section{Giving Reasons in Community Law}

Article 173 of the EEC Treaty provides that Community actions must satisfy "essential procedural requirements." 16 The ECJ has repeatedly held that the giving reasons provision of Article 190 is an essential procedural requirement. Article 190 applies to regulations, directives, and decisions of both the Council and the Commission. Thus, giving reasons constitutes a procedural requirement for both administrators engaged in supplementary lawmaking and implementation and legislators engaged in primary lawmaking. Both the Council and the Commission exercise a mixture of executive and legislative functions. However, with some exceptions, the Council enacts primary legislation comparable to congressional statutes in the U.S., and the Commission issues secondary legislation roughly comparable to rulemaking by American executive agencies and independent commissions and with roughly the same range from highly general to quite specific. Both bodies also make highly particularized administrative decisions. Thus, at the very minimum Article 173 and Article 190 ensure that the key decisionmaking bodies of the Community follow the procedural giving reasons requirement. As a matter of both administrative and constitutional law, the requirement is roughly equivalent to the concise and general statement of basis and purpose of the APA and the requirement of due process of the Fifth Amendment.

The comparability of U.S. and Community administrative law is obvious. The comparability in constitutional law exists only if the argument about reasonableness and reason giving that I made earlier is convincing. Even if the argument is convincing, however, a paradox must be noted. Substantive, not procedural, due process imposes a giving reasons requirement on the U.S. Congress. Further, the demand is not imposed directly on Congress as a formal procedural one, but instead is imposed only in the course of litigation subsequent to passage of the statute. If the statute faces a constitutional challenge, someone must give reasons for it. Ideally the someone will have been Congress, but sometimes the litigators defending the statute can successfully do the reason giving. Thus the constitutional imposition of a giving reasons requirement on

16 Treaty Est the Eur Eco Comm, Art 173. 
legislators is a formal, direct procedural requirement in the Community and is an indirect, substantive one in the U.S.

\section{A. Pure Procedure}

The American experience in both administrative and constitutional law raises the question of whether the Community giving reasons requirement is substantive as well as procedural. Further, how extensive are the Community's procedural demands? We have seen that the APA reasons requirement has grown into a substantive demand that the agency give complete and even synoptically correct reasons. Further, the APA requires that the agency provide a counter-reason to match every reason offered by those opposing the agency's rule. We have seen that under constitutional due process or its contemporary twin, equal protection, the legislature is sometimes compelled to show that an adopted rule achieves legitimate goals with minimum cost to individual rights. Is Article 190, as now construed by the ECJ, more than a purely procedural requirement, and is there room for future substantive growth?

First and foremost, Article 190 is a pure procedural requirement. In theory, the ECJ will invalidate a Council or Commission action about which it has no substantive qualms whatsoever solely on the grounds that reasons have not been given. This procedural rigor is tempered in various ways. The ECJ has repeatedly held that the nature and extent of the reasons that must be given depend on the nature and circumstances or context of the particular action taken. ${ }^{16}$ Just as the "concise and general statement of basis and purpose" language of the APA suggests, it is impractical and self-defeating for courts to demand that legislative bodies provide a detailed account of all the deliberative analysis that led to the final statutory outcome. All that a legislature could do to meet such a demand would be to pile up on the judicial rostrum all of the staff studies, internal memoranda, committee reports, and debate that led to the final outcome. At the other extreme, a particular administrative decision about the precise legal liability of a particular individual or enterprise should carry with it a set of quite particularized and detailed reasons. The ECJ tends to demand only general reasons for major legislation and to demand more detailed reasons for more circumscribed decisions. ${ }^{17}$

\footnotetext{
16 Case 819/79, Germany u Commission, 1981 ECR 21, 36; Case 1251/79, Italy v Commission, 1981 ECR 205, 221-22; Case 238/86, Re Skimmed Milk Powder: Netherlands v Commission, 1988 ECR 1191, 1195, 1989:3 CMLR 399 at I 15.

${ }^{17}$ Thus, in Case 5/67, Beus v Hauptzollamt Munchen, 1968 ECR 83, the Court held:
} 
The requirements of Article 190 are satisfied for measures of general application if the "[c]onsiderations upon which the defendant's decision rests are clear." 18 Where general regulations take the form of a constantly changing series of decisions such as market quotas, detailed reasons need not be given for each change. Reference back to the reasons given in the preambles of the previous quotas may be sufficient if the ECJ could possibly deduce the general market organization scheme formed by the quotas. ${ }^{10}$ The ECJ sometimes echoes the American APA language when dealing with major Commission or Council mandates:

[I]t is sufficient . . . to set out, in a concise but clear and relevant manner, the principal issues of law and of fact upon which [such action] is based and which are necessary in order that the reasoning which has led the Commission to its Decision may be understood. ${ }^{20}$

As with APA courts, however, one should note that the language here lends itself potentially to a judicial demand for "reasoned elaboration" by the Commission rather than a mere list of unrationalized assertions. Indeed, the Advocate General in Consorzio Cooperative D'Abruzzo $v$ Commission ${ }^{21}$ seems to be calling for some movement in that direction. On the other hand, although general acts only require reasons "in essence," even where actions are general in form they trigger a necessity for more detailed rea-

It is a question in the present case of a regulation, that is to say, a measure in-
tended to have general application, the preamble to which may be confined to
indicating the general situation which led to its adoption, on the one hand, and
the general objectives which it is intended to achieve on the other. Consequently,
it is not possible to require that it should set out the various facts, which are often
very numerous and complex, on the basis of which the regulation was adopted, or
a fortiori that it should provide a more or less complete evaluation of those facts. Id at 95 .

${ }^{18}$ Case 61/86, Re Clawback on Export of Sheep: United Kingdom v Commission, 1988 ECR 431, 457, 1988:2 CMLR 98, 107 (Advocate General's opinion), and the cases cited therein. For a useful summary of recent case law, see Case 264/86, Re Tuna Producers: France v Commission, 1988 ECR 973, 1989:1 CMLR 13, 24-25 (Advocate General's opinion).

${ }^{19}$ Case 250/84, Eridania zuccherifici nazionali SpA v Cassa Conguaglio Zucchero, 1986 ECR 117; Case 37/83, Rewe-Zentrale AG v Direktor Der Landwirtschaftskammer Rheinland, 1985:2 CMLR 586. See also Case 167/88, Association Generale Producteurs De Ble $(A G P B) \cup$ Office National Interprofessionnel Des Cereales (ONIC), 1991:2 CMLR 61, holding that a full statement of reasons is not required when "regulations fall within the general scheme of the body of measures of which they form a part." Id at 85.

20 Case 24/62, Germany v Commission, 1963 ECR 63, 69, 1963 CMLR 347, 367.

${ }^{21}$ Case 15/85, Consorzio Cooperative D'Abruzzo v Commission, 1987 ECR 1005, 1020, 1988:1 CMLR 841, 854. 
sons when the rules are not general and abstract but a series of individual decisions. ${ }^{22}$

In attempting to construct this gradation, the ECJ is clearly heavily influenced by the most basically procedural root of the giving reasons requirement-the desire for transparency in government affairs. As we noted earlier, quite apart from any desire we may have that government decisions be substantively correct or even lawful, we have a desire to know what the government decisions are and the reasons the government made them. After all, we often don't know what the decision is unless we are told the reasons for it.

Thus, in rejecting a Member State's challenges to directives or other major Council actions, the ECJ has sometimes ruled that since the challenging Member State participated, as a member of the Council, in the very process of reaching the decision, the Member State's own participation must have revealed to it all of the reasons for the decision. In those circumstances, the complaining state has received all the reasons to which it is entitled, and Article 190 only requires a highly general formal statement of reasons. The ECJ has even applied this logic to the less direct participation of Member States in Commission decisions. ${ }^{23}$ In cases involving individual enterprises who must have become familiar with the agency's reasoning in the course of the negotiations, the ECJ has held that a not very complete, formal statement of reasons accompanying a final decision will suffice. ${ }^{24}$ In one rather curious case, the ECJ allowed an extremely cryptic Commission finding of law to pass muster under Article 190. ${ }^{25}$ The ECJ apparently felt that any experienced Community lawyer could easily explain to his client the chain of legal reasoning that must have led to the conclusion reached. ${ }^{26}$

22 This is one Advocate General's opinion in Case 232/81, Agricola Commerciale Olio Srl v Commission, 1984 ECR 3881, 3895, 1987:1 CMLR 363, 377; Case 45/86 Re Generalised Tariff Preferences: Commission v Council, 1987 ECR 1493, 1988:2 CMLR 131.

${ }^{23}$ Case 238/86, Re: Skimmed Milk Powder, 1988 ECR 1191, 1989:3 CMLR 399; Case 68/86, Re Agricultural Hormones: United Kingdom v Council, 1987 ECR 1381, 1988:2 CMLR 543; Case 333/85, Mannesmannröhren-Werke AG v Council, 1987 ECR 1381, 1988:2 CMLR 627; Re Tuna Producers: France v Commission, 1988 ECR 973, 1989:1 CMLR 13.

24 Case 238/86, Re Skimmed Milk Powder, 1989:3 CMLR 399.

${ }^{25}$ Case 41/83, Re British Telecommunications: Italy v Commission, 1988 ECR 111, 1985:2 CMLR 368 .

${ }^{26}$ Id. 
B. The Transition from Pure Procedure to Substance

The ECJ has adopted a standard formula for expressing the transparency requirement:

In imposing upon the Commission the obligation to state reasons for its decisions, Article 190 is not taking mere formal considerations into account but seeks to give an opportunity to the parties of defending their rights, to the Court of exercising its supervisory functions and to member-States and to all interested nationals of ascertaining the circumstances in which the Commission has applied the Treaty. ${ }^{27}$

That very formula, however, constitutes a transition from procedural to substantive reasons that is strikingly comparable to the American transition from procedural to substantive due process in the famous Minnesota Rate Case. ${ }^{28}$ In that case, the Supreme Court held that a railroad rate statute violated due process because it did not provide for judicial review of the rate orders of the state railroad commission. At first glance, the case appears to be one of pure procedural due process. The statute falls because it fails to provide a procedure, namely an appeals procedure. When one asks, however, why it is necessary to have an appeals procedure, and what the courts are to do when such a procedure is put in place, the substantive hook in the procedural case becomes clear. The Supreme Court insisted that judicial review is a necessary procedure because the Constitution demands that judges determine whether the rates initially set are substantively correct.

If the Court of Justice were concerned only with procedure and transparency then its rule would read, "The Community organ must give sufficient reasons to allow relevant parties to know the basis of its decision." There would, of course, be continuing quibbles about how much basis, but the goal of transparency would clearly be the sole good. By adopting the formula it does, however, the ECJ links the giving reasons requirement firmly to judicial review. This is so not only in the specific invocation of review but also in the specification of transparency for the parties. For in reality, the ECJ is saying that the Community organ must give the

${ }^{27}$ Case 24/62, Germany v Commission, 1963 ECR at 69; 1963 CMLR at 367. See also Case 37/83, Rewe-Zentrale AG v Direktor Der Landwirtschaftskammer Rheinland, 1984 ECR 1229, 1985:2 CMLR 586.

${ }^{28}$ Chicago, Milwaukee and St. Paul Ry. Co. v Minnesota, 134 US 418 (1890). 
individual party sufficient information so that the party can make an informed judgment about whether to sue or not.

The paradox is a rather nice one. A court says: "(1) You must give reasons; and (2) We have the power of judicial review." At the same time, the court is saying, "We will review simply to see whether you have met a purely formal procedural requirement. If we see a list of reasons, you pass, unless of course someone can show that as a matter of fact these were not your real reasons."

A court that says, "You must give reasons so that we can review" is, however, saying something quite different. Requiring an agency to give reasons in order for a court to review it allows the court to decide whether the agency was justified in reaching the decision it reached. The reasons demanded after all are reasons about substance as well as procedure. It would not be a sufficient reason for the agency to say: "Well, the reason for this rule is that we met on Tuesday and passed it by majority vote." The agency must offer substantive reasons for what it did. Lo and behold, procedure has turned into substance. Article 190 becomes not only a guarantee to the citizens of the transparency of their government, but also a guarantee to the ECJ of its powers of substantive judicial review.

I am not claiming that this point is a big revelation. Unlike the U.S. Supreme Court, which had to transpose the purely procedural language of the due process clauses into substantive reasonableness review, the European Court of Justice had plenty of constitutional authority for substantive judicial review even without Articles 173 and 190. The ECJ's reading of Article 190 as instrumental to its review powers granted elsewhere is unexceptionable. However, Article 190 now mandates not only that Community organs give reasons but that they give good reasons.

In American administrative law, the movement from procedural to substantive review has come through a middle ground. That middle ground was the expansion of the APA's "concise and general statement" reasons requirement into the requirements of rulemaking record, dialogue, and reasoned elaboration. So when a transition from procedure to substance inheres in Article 190, we are alerted to look for similar movements in the giving reasons law of the Community. However, the nature of the Council as a general legislature would lead us to expect that if a movement comparable to the D.C. Circuit's transformation of the APA is occurring in the Community, the movement will probably be most evident in Commission actions. 
The ECJ does not begin where the D.C. Circuit did, with an APA that on its face distinguished between formal rulemaking where a record was required and informal rulemaking. Article 190 would certainly allow the ECJ to require as much of a record as it wanted for Commission decisions, to create a situation where the rulemaking record requirement in an informal rulemaking is just as elaborate as that in a formal rulemaking or adjudication. In fact, the Commission has always been in the habit of compiling rather elaborate records. ${ }^{29}$ Thus, the Court of Justice has not had to go through the struggle that the D.C. Circuit did to get the kind of extended substantive record before it that a court needs to secondguess agency lawmakers. The ECJ sees relatively full records and has the clear authority to ask for even more extended records if it reads Article 190 as requiring them.

The dialogue dimension of giving reasons is extremely prominent in EC case law, but in the plaintiffs' pleadings rather than the ECJ's opinions. Especially in cases involving Commission decisions concerning particular enterprises or product lines, complaining parties frequently invoke Article 190 and point to particular unanswered arguments they have raised with the Commission. While rarely successful, this demand for dialogue can be met in one of two ways: either the ECJ finds that the Commission has in fact responded to the particular argument, or the court finds that the Commission has given a sufficient response in the matter as a whole to allow the party to determine whether its legal rights have been violated. In Stichting Sigarettenindustrie $v$ Commission the ECJ says:

The Court has consistently held that, although under Article 190 of the Treaty the Commission is obliged to state the reasons on which its decisions are based, mentioning the factual and legal elements which provide the legal basis for the measure and the considerations which have led it to adopt its decision, it is not required to discuss all the issues of fact and law raised by every party during the administrative proceedings. ${ }^{30}$

Of course, each time the ECJ resolves an Article 190 complaint by finding that the Commission actually did respond to the

\footnotetext{
20 The interrelation of the Council and the Commission pushes in that direction quite apart from judicial review.

so Joined Cases 240/82, 242/82, 261/82, 262/82, 268/82, 269/82, Stichting Sigarettenindustrie $v$ Commission, 1985 ECR 3831, 3882, 1987:3 CMLR 661, 711.
} 
point raised, the ECJ acknowledges, in a sense, the validity of interpreting Article 190 as requiring dialogue. For instance, in Remia $B V$ and Others $v$ Commission, ${ }^{31}$ the ECJ stated that with regard to the duty to state reasons, the contested decision clearly contains a sufficient answer to the arguments put forward by the applicants. ${ }^{32}$ In Technointorg $v$ Commission and Council, ${ }^{33}$ the complaining party pushed an extreme form of the dialogue requirement. The Advocate General rejected the Article 190 complaint, but he did so by showing in considerable detail that there really was all the dialogue to which a party would be reasonably entitled. The ECJ adopts the same approach, although it provides a little less detail than the Advocate General. ${ }^{34}$

Yet, a court acknowledgement of a dialogue requirement would only be complete if there were at least a few major cases in which the Commission decisions were invalidated for failure to make an adequate response to the regulated parties. Such cases do not exist. In this sense, though Community law reflects pressure toward a dialogue requirement, the ECJ has yet to move decisively to such a requirement.

The basic reason that the parties push and the ECJ resists dialogue lies in the difference between transparency and participation. Courts are likely to be initially hostile to demands for dialogue. Such requests are the last resort of regulated parties who have no substantive arguments left. Moreover, if dialogue claims are judicially accepted, they lead to a more and more cumbersome administrative process because the regulated parties will be encouraged to raise more and more arguments to which the regulating agency will have to respond. If the only instrumental value for giving reasons is transparency, the courts will resist dialogue demands. One can discover an agency's actions and purposes without the agency rebutting every opposing argument.

The dialogue requirement has come into American law because American courts have been in pursuit not only of trans-

${ }^{31}$ Case 42/84, Remia BV and Others v Commission, 1985 ECR 2545, 1987:1 CMLR 1.

${ }^{32}$ Id, 1985 ECR at 2753.

ss Joined Cases 294/86 and 77/87, Technointorg v Commission and Council, 1988 ECR 6077, 1989:1 CMLR 281.

34 See also, Case 238/86, Re Skimmed Milk Powder, 1988 ECR 1191, 1989:3 CMLR 399 (both the Advocate General and the court excused the paucity of reasons given on the grounds that the complaining party had been fully informed and fully responded to participant in the decision process); Case 240/84, NTN Toyo Bearing Co. Ltd. v Council, 1987 ECR 1809, 1989:2 CMLR 76 (excusing a similar paucity on the ground that the Community had requested a dialogue with the complaining party and that the party did not seize the opportunity). 
parency but participation in the regulatory process. The notice and comment requirements of the APA incorporate this participation value into American administrative law. The pluralist political theory that has been the guiding orthodoxy of post-war American politics demanded that every group with an interest be allowed to participate in every governmental process affecting that interest. American courts adopt the dialogue requirement as a device for facilitating judicial review of regulating agencies' commitment to group participation. The notice and comment demands of the APA can be met merely by allowing the interest groups to speak. The agency need not really listen. If, however, the agency is required to respond to each thing the groups say, then the agency must at least listen enough to make a response. Courts invented the dialogue requirement to ensure that the agencies were not only receiving the arguments of non-governmental participants but really taking them seriously.

If the ECJ sticks closely to transparency as the sole goal of Article 190, the ECJ is unlikely to move towards a dialogue requirement. Yet participation in government by interests affected by government decisions presents an increasingly compelling value in contemporary society, particularly where environmental matters are involved. The ECJ has already, however unintentionally, opened one avenue for linking participation to Article 190 by stating that the Council need not give full reasons to the Member States where they have participated in the decisions. To be sure, these ECJ opinions are transparency-based. They require that those Member States already know what was going on because they were there. Nevertheless they create an opening for counterarguments from complainants who were not present and claim that, therefore, they need the Commission to be responsive. In short, full transparency can only be achieved through participation or through dialogue as a form of participation.

Complainants have not only pushed for dialogue but for reasoned elaboration under Article 190. If the Council gave wrong reasons, it must fail the test of Article 190, at least if Article 190 is more than a purely formal demand that reasons, even wrong ones, be given. The ECJ's jurisprudence has firmly established that wrong reasons are not enough under Article 190. Accordingly, someone invoking Article 190 does not necessarily have to show that the Community organ offered reasons that were false, in the sense of not being the real reasons motivating the Community's action. Further, such a showing may not be sufficient to invoke Ar- 
ticle 190. However, showing that the reason given is incorrect as to fact, law, or logic is sufficient. ${ }^{35}$

In some cases the ECJ discusses the reasons given, showing that they are indeed good reasons. To be sure, cases in which the ECJ has found a Community organ in violation of Article 190 because its reasons were not good enough are few and far between. Yet the ECJ's willingness not simply to count but to march through the reasons given, commenting on their adequacy, indicates that at least an embryonic reasoned elaboration requirement already exists. Further, the requirement goes beyond transparency to a requirement of giving substantively good reasons. A substantive criteria of reasoned elaboration or giving good reasons is, of course, closely related to the ECJ's general inclination or disinclination to do substantive review of the Commission's work, a point we will return to later.

We have seen that the final stage in the evolution of the development in American administrative law was the judicial demand that the agencies engage in synoptic decisionmaking, that is, that they respond adequately not only to all issues actually raised by interested parties, but also to all issues. In short, the demand is that the agency do a perfect job of decisionmaking with the strong implication that the agency must arrive at the perfect, or at least the best, decision. Obviously, if the ECJ has not moved even as far as a full dialogue standard, the ECJ is very far indeed from turning the requirement of giving reasons into synopticism. If any hints of a synoptic standard exist in the ECJ's jurisprudence, they lie not in Article 190 review but in the ECJ's various assertions of substantive review per se, for instance its claim to do "comprehensive" review of the Commission's anti-competition decisions. ${ }^{36}$

In rejecting dialogue, there are a number of instances in which the ECJ has rather explicitly rejected synopticism. In Re Skimmed Milk Powder: Netherlands $v$ Commission, ${ }^{37}$ for instance, the court states that "the obligation to state reasons relates to decisions that are actually adopted and in those decisions the Commission is not required to explain the reasons for which it did not adopt a sugges-

${ }^{36}$ For instance, if the principal claim is that the Council chose the wrong legal basis for a directive, that it acted under Article 235 when it should have acted under some other article, then a subsidiary reasons claim is almost automatic. If the Council was wrong to act under Article 235, then whatever reasons it gave for acting under Article 235, and/or the citation of Article 235 as the reason for its action, must fail Article 190.

36 See Case 246/86, Re Roofing Felt Cartel: Société Coopérative Des Asphalteurs Belges ("Belasco") v Commission, 1989 ECR 2117, 1991:4 CMLR 96.

${ }^{37}$ Case 238/86, Re Skimmed Milk Powder, 1988 ECR 1191, 1207, 1989:3 CMLR 399. 
tion made by its departments." 38 In Remia and Nutricia $v$ Commission ${ }^{39}$ the ECJ states that Article 190 "does not require the Commission to discuss all the matters of fact and of law which may have been dealt with during the administrative proceedings." 40

Finally, the ECJ has given some hints as to whether giving post hoc reasons will suffice. As a general proposition, post hoc reasons, offered during litigation, would meet one prong of the ECJ's transparency requirement. Such reasons giving would allow the court to fulfill its review function. Only reasons contemporaneous to the initial government action, however, would seem to satisfy the other prong. Presumably, parties adversely affected by the government action would only be in a position to calculate whether the government violated their rights-whether they should litigate-if the parties were aware of the Community organ's reasons at the time the action occurred. Surely it would be unfair to require parties considering litigation to wait until after the suit began to acquire the information they need in order to decide whether to litigate. Yet, the ECJ's position on this question is not entirely clear.

In Re The Protection of Battery Hens: United Kingdom v Council, ${ }^{41}$ the ECJ ruled that the Council's secretariat may not make post hoc alterations in the reasons given in the preambles of Council directives on which the Council has voted. However, such alterations would not really appear to fail either prong of the transparency test. Battery Hens suggests quite a different aspect of the post hoc reasoning problem. At the deepest level, modern administrative law has left unresolved a basic tension between two approaches to governing authority. Under one approach we ask: "Is the government action reasonable?" That is: "Can good reasons be given for the action? Can it be justified?" Under the other approach we ask: "Did the government act for good reasons?" That is: "Did the government act out of legitimate or illegitimate motives? Did it have lawful or unlawful intentions?" Because the subjective intentions of government decisionmakers are typically difficult to discern, particularly because most government actions are compromises among multiple goals and interests, reviewing courts

sa Id, 1988 ECR at 1207, 1989:3 CMLR at 416.

3o Case 42/84, Remia BV, 1985 ECR 2545, 1987:1 CMLR 1.

40 Id, 1985 ECR at 2573, 1987:1 CMLR at 29. See also Case 246/86, Re Roofing Felt Cartel: Belasco v Commission, 1989 ECR 2177, 2194, 1991:4 CMLR 96.

1 Case 131/86, Re The Protection of Battery Hens: United Kingdom v Council, 1988 ECR 905, 1988:2 CMLR 364. 
are pushed toward "can reasons be given" and, thus, toward accepting post hoc reasons. On the other hand, courts never quite abandon the notion of subjective intent, as such doctrines as detournement de pouvoir suggest. Post hoc reasons that are obviously designed to mask, correct, or substitute for the real government motivation must be judicially scrutinized.

In Re Generalised Tariff Preferences: Commission $v$ Coun$\mathrm{cil}^{42}$ the ECJ treats post hoc reasons unfavorably, but only to bolster its holding that the Council was really using the wrong legal basis for a directive in which the official preamble mentions no legal basis at all. Reference to post hoc reasons is used not to allow a post hoc screen for the subjective intent of the government organ but, instead, to penetrate to the actual subjective intentions. ${ }^{43}$

On the other hand, the ECJ does find acceptable one kind of post hoc reasoning particularly favored by lawyers. Where a government organ has made a general finding of law, comparable to those made by courts, the government may be required to give the legal reasoning supporting that finding. One reason for this position may well be a transparency consideration. Confronted by a formal finding of law, the parties' lawyers can usually quickly reconstruct the legal reasons or arguments that lie behind it. Another basis for the ECJ's position is probably one of redundancy: where a general legal conclusion is involved, the question of whether the government organ meets the giving reasons requirement and the question of whether the government decision is substantively correct, or lawful, is the same question. The ECJ is content to hear the government's legal reasoning in the course of litigation and if the reasoning fails, the government action fails. The Article 190 question either need not be reached or is automatically answered. ${ }^{44}$

American experience indicates that the most crucial aspect of the giving reasons requirement may be that it serves as a way of softening and somewhat disguising substantive judicial review. Thus, the requirement softens and disguises the ultimate dilemma

${ }^{2}$ Case 45/86, Re Generalised Tariff Preferences: Commission v Council, 1987 ECR 1493, 1988:2 CMLR 131.

${ }^{43}$ In Regina v Minister of Agriculture Fisheries and Food and Sec'y of State for Health ex parte Federation Europeenne de la Sante Animale, 1988:3 CMLR 661, 672 (English High Court, Queen's Bench Division), the plaintiff sought, unsuccessfully, to argue that the Council violated Article 190 " [b]y indicating insubstantial or insufficient reasons ... and omitting to state a further and substantial reason." In essence the complaint was that the Council had not given its real reason.

4S See Commission v Council, 1990:2 CEC (CCH) 773. 
of judicial review. The ultimate dilemma is, of course, that judges feel a strong urge and are typically under a constitutional mandate, self-proclaimed or otherwise, to strike down wrong government decisions. At the same time, judges typically have no claim to the technical expertise necessary to declare a decision wrong in the face of the expert government agency's determination that it is right.

The Court of Justice clearly has encountered the problem. Article 33 of the European Coal and Steel Community Treaty provides:

The Court may not, however, examine the evaluation of the situation, resulting from economic facts or circumstances, in the light of which the High Authority took its decisions or made its recommendations, save where the High Authority is alleged to have misused its powers or to have manifestly failed to observe the provisions of this Treaty or any rule of law relating to its application.

Nothing could more clearly command the ECJ both to defer to administrative expertise and, at the same time, not to defer. Complete deference to fact-finding by another government organ would mean no judicial review at all. If the agency can allege any facts it wants, it can hardly lose on the law. The EEC Treaty contains no such provision. Early on, the ECJ staked out a strong substantive judicial review position. Subsequently, the ECJ has maintained this position, while also proclaiming a high degree of deference to Commission and Council fact finding. ${ }^{45}$

The giving reasons requirement provides a partial solution to this tension in two ways. First, the requirement can provide a halfway house between procedural and substantive review in which judicial substantive objections are couched in procedural language and the court exercises a suspensive rather than absolute veto. The ECJ says "because you did not give good enough reasons, your action fails to meet an 'essential procedural requirement." Presumably the Community organ may then proceed, without changing its substantive decision, to remedy its procedural fault by giving more and better reasons. Second, a giving reasons requirement can become full-scale substantive review without quite full-scale challenge to the expertise of the expert government organs. The moves from "did not give reasons" to "did not give good reasons" to "did

15 T.C. Hartley, The Foundations of European Community Law 427-29 (Clarendon Press and Oxford Univ Press, 2nd ed 1988). 
not give good enough reasons" are easy and virtually unidentifiable moves. The difference between "did not give good enough reasons" and "did not adopt a good enough policy" is nonexistent in many instances. Where the government organ did give reasons but the ECJ says the reasons are not good enough, the court was often actually disagreeing with the government organ on the substance of the policy. Indeed, in rejecting various offered reasons, a court can usually signal what substantive policy it would accept.

Thus, if a court is inclined to hover somewhere between total deference and completely activist substantive review, the giving reasons requirement provides a flexible tool of review. Furthermore, one measure of the degree of a court's exercise of substantive review is the number of times it finds that government organs have not given reasons.

\section{The European Court of Justice Experience with Substantive Review}

The Court of Justice has shown certain proclivities toward using giving reasons as a substantive review device, but the court strikes down very few actions of the Commission and Council on Article 190 grounds alone. A review of some recent cases indicates the substantive review potential of the giving reasons doctrine.

For example, in Generalised Tariff ${ }^{46}$ both the Advocate General and the ECJ inextricably combine giving reasons and pure substantive review. In one directive, the Council simply does not cite any article of the treaties as the basis of its action. The Advocate General argues that the Council has not met an essential procedural requirement, but nonetheless the Council argues that the directives ought not to be invalidated because they are substantively acceptable. The ECJ notes that the Council did not cite any EEC Treaty article because the members could not agree on whether to cite Article 113, which does not require a unanimous Council vote, or Article 235, which does. The ECJ goes on to note that the Council then went to unanimous voting and so the Council must have been acting under Article 235. The ECJ concludes that the Council action is invalid because it was based on Article 235 when it should have been based on Article 113. Accordingly, the ECJ invalidates the Council action on substantive grounds.

Here, the ECJ might have voided the Council's action under Article 190 because the Council had failed to give any legal reason

46 Case 45/86, Re Generalised Tariff, 1987 ECR 1493, 1988:2 CMLR 131. 
at all for its action, for example, the Council cited no legal basis for its action. Alternatively, the ECJ might have passed the Council's action under Article 190 because its resort to unanimous voting signaled that the Council had in reality chosen Article $235 .{ }^{47} \mathrm{In}$ stead, the ECJ states that:

[T] he contested regulations are measures falling within the sphere of the common commercial policy and ... since the Council had the power to adopt them pursuant to Article 113 of the Treaty, it was not justified in taking as its basis Article 235.

It is clear from the foregoing that the contested regulations do not satisfy the requirements laid down in Article 190 of the Treaty with regard to the statement of reasons and that, moreover, they were not adopted on the correct legal basis. Consequently, they must be declared void. ${ }^{48}$

We shall never know if the Council failed Article 190 on the pure procedural ground of failing to state any reasons at all, or on a substantive ground, for having implicitly stated a wrong reason. ${ }^{48}$

In Re Revaluation of the Green Mark: Germany $v$ Commission, ${ }^{\text {,o }}$ the German government asserted that the Commission violated Article 190 by issuing an internally contradictory regulation. Germany argued that the regulation treated market price and buying-in price as different from one another when in fact the buyingin price necessarily became the market price. The Advocate General responded with economic data showing that in the previous four months of 1984, the buying-in and market prices had in fact been different. The ECJ rejected the Article 190 claim on the grounds that "the German government has not shown that the calculation on which the provision ... is based was unrealistic and thus that the regulation was self-contradictory." 51 This outcome

\footnotetext{
${ }^{47}$ In this case, the Commission argued that citation of a legal basis has to be explicit to satisfy Article 190. 1987 ECR at 1497. The Council argued that implicit citation was sufficient under Article 190. Id at 1498.

48 Id (emphasis in original).

48 In a case in which the ECJ did not reach the Article 190 issues, the Advocate General argues that if there is manifest error or abuse of discretion evident on the face of the reasons given, then Article 190 has been violated. See Case 61/86, Re Clawback on Export of Sheep: United Kingdom v Commission, 1988 ECR 431, 444, 1988:2 CMLR 98, 107. In Case 240/84, NTN Toyo Bearing Co. Ltd. v Council, 1987 ECR 1809, 1858, 1989:2 CMLR 76, 112, the ECJ suggests that a plaintiff may succeed under Article 190 if it can show that the reasons given "exceeded the margin of discretion ....." Id.

${ }^{30}$ Case 278/84, Re Revaluation of the Green Mark: Germany $v$ Commission, 1987 ECR 1, 1988:1 CMLR 632 .

${ }^{\circ 1}$ Id, 1987 ECR at $46-47,1988: 1$ CMLR at 655.
} 
may be taken as deference to Commission expertise. However, the outcome also may be taken as indicating that if the Commission's calculation was shown to be substantively unsound, generating a self-contradiction, then the ECJ should have found a breach of Article 190.

Re Roofing Felt Cartel: Belasco v Commission"52 ("Belasco") also concerns alleged contradictions in reasons given. The complaining party alleges five such contradictions in the Commission's reasons. In the portion of its opinion labelled "Inadequacy of the Statement of Reasons," the ECJ rejects the dialogue requirement urged upon it by Belasco.

As regards the alleged failure to reply to the applicants' arguments, . . . although under Article 190 . . . the Commission is required to set out all the circumstances justifying the adoption of a decision and the legal considerations which led the Commission to adopt it, [Article 190] does not require the Commission to discuss all the matters of fact and of law which may have been dealt with during the administrative proceedings. ${ }^{53}$

Yet, in another portion of its decision, the ECJ nevertheless goes point-by-point through each alleged contradiction and holds that the Commission was substantively correct in each instance.

The upshot of Belasco may be important on the question of post hoc reasoning. The ECJ rejects dialogue but then examines substantively each point the party seeking dialogue wished to raise. The ECJ implied that the Commission need not answer the regulated party at the time of its initial decision. However, at the time of judicial review, the Commission will have to respond to whatever issues raised by the regulated party the ECJ thinks significant. Belasco is not, of course, nearly as striking a case of using Article 190 for substantive review as it would be if the ECJ had found against the Commission. However, the ECJ clearly does state that the Commission passes Article 190 not simply because it gave reasons, but because it gave good and correct reasons. ${ }^{54}$ The

s2 Case 246/86, Belasco, 1989 ECR 2117, 1991:4 CMLR 96.

os Id, 1989 ECR at 2194.

54 The ECJ reached a similar result in Joined Case 424/85, 425/85, FRICO $v$ Voedselvoorziening In-en Verkoopbureau, 1987 ECR 2755, 1988:3 CMLR 733. In Case 248/84, Re German Regional Aid Plans: Germany v Commission, 1987 ECR 4013, 1989:1 CMLR 591, the ECJ does strike down a Commission action for failure to satisfy Article 190. However, the holding is really based on clear error of law on the face of the record rather than a 
ECJ's message is that giving reasons is not merely a procedural requirement but, rather, that good reasons must be given. ${ }^{\mathrm{ss}}$

The statement of reasons required by Article 190 of the Treaty relates to the decision actually adopted. In principle, it would be quite excessive to require the Commission to explain the reasons for which it did not take alternative decisions. In Skimmed Milk Powder, the Advocate General states that in his view, the applicant "bears the onus of demonstrating that a different solution should have been adopted." not show that it has considered and rejected for good reasons each and every alternative other than the one it adopted, but the Commission must have good reasons for the one it did adopt.

Remia and Nutricia ${ }^{57}$ is an instance where the ECJ obviously does feel the conflict between substantive review and deference to technical expertise. Advocate General Lenz has clearly been seeking to move in the direction that U.S. courts took in expanding the concise and general statement of basis and purpose requirement of the APA. In both Remia and Akzo Chemie BV v Commission, ${ }^{68}$ Lenz adopts the formula that Commission statements of reasons must be "clear and relevant." In both cases, in a rather conclusory way, he proposes that the Commission's reasons are concise but not "clear and relevant," and so fail Article 190. In both cases, the ECJ rejects the "clear and relevant" formula, and in both cases, the ECJ upholds the Commission. In Akzo, the ECJ speaks of "adequate" reasons and is far less conclusory than the Advocate General. The ECJ cites various paragraphs of the Commission's decision which it says give enough reasons.

Remia involves Article 85(1), one of the "anti-trust" or competition articles of the Treaty. The ECJ states:

The Court must therefore limit its review . . . to verifying whether the relevant procedural rules have been complied with, whether the statement of the reasons for the

substantive failure in the Commission's analysis and is, in a sense, a pure procedural holding that the Commission fails Article 190 because it gives no reasons at all.

so This is clearly stated in the Advocate General's statement in Case 238/86, $R e$ Skimmed Milk Powder, 1988 ECR 1191, 1989:3 CMLR 399. He firmly rejects synoptic demands, but does suggest that under Article 190 a complaining party may prevail if it can show that the Commission was substantively wrong. 1988 ECR at 1191 (referring to Advocate General's opinion in Case 327/85, Re Skimmed Milk Powder, 1988 ECR 1065, 1080).

s6 Id.

${ }^{67}$ Case 42/84, Remia $B V$ and Others $v$ Commission, 1985 ECR 2545, 1987:1 CMLR 1.

ss Case 53/85, Akzo Chemie BV v Commission, 1986 ECR 1965, 1982, 1987:1 CMLR $231,251$. 
decision is adequate, whether the facts have been accurately stated and whether there has been any manifest error of appraisal or a misuse of powers. ${ }^{69}$

Here, the ECJ clearly is backing away from substantive review in the face of Commission economic expertise. As to Article 190, the ECJ rejects "clear and relevant" in favor of "adequate" and finds the Commission's reasons adequate. However, the ECJ actually marches through the Commission's reasons, arguing that they were sufficiently responsive to the actual circumstances and met the normal transparency requirements. Yet, the ECJ does not comment at all on whether the reasons were substantively correct. ${ }^{\text {60 }}$

In Remia, stating facts and giving reasons are tandem requirements. The ECJ does say that it exercises review to determine whether facts are accurately stated. Yet, the court arranges its sentence structure so that facts must be accurate and reasons adequate. The reasons need not be accurate. This may appear to be splitting hairs. The point is, however, that the ECJ is actually claiming to review whether the simple, first order facts are accurately stated, and whether the Commission's reasons indicate that the Commission has considered those facts, but the ECJ disclaims competence to review the economic analysis that the Commission applied to the facts in order to reach its decisions. Thus, the Commission must give responsive reasons but not necessarily good reasons. At the very least, the ECJ avoids judging the substance of the reasons. Instead, the court retreats from "comprehensive" to an "arbitrary and capricious, abuse of discretion" style of review.

Americans have recently observed two equal and opposite Supreme Court attitudes toward deference to agency expertise. In Motor Vehicle Mfrs. Association of the United States Inc. $v$ State Farm Mutual Auto Insurance Co. ${ }^{62}$ the Supreme Court seemed to

so Case 42/84, Remia BV, 1985 ECR at 2575, 1987:1 CMLR at ๆ $34-37$.

${ }^{\circ}$ Id.

61 In this context, Advocate General Lenz's opinion becomes clearer. He is seeking to tell the ECJ that it can deal with the tension between review and expertise in a more active way than by retreat to a lower than "comprehensive" review standard. Confronted by the Commission's expertise, the ECJ can invoke the suspensive veto of Article 190 rather than the complete, substantive veto of finding an Article 85(1) violation. In this manner, the ECJ can use Article 190 to voice substantive disagreement with Commission anti-trust decisions. Moreover, by using Article 190, the court avoids claiming that it knows more economics than the Commission does. I do not know whether the ECJ rejects this approach because it prefers to retreat in anti-competition matters, or simply because it agreed substantively with the Commission's decision.

${ }^{-2}$ Motor Vehicle Mfrs. Association of the United States Inc. $v$ State Farm Mutual Auto Insurance Co., 463 US 29 (1983). 
demand that the agencies do synoptic decisionmaking subject to synoptic review. In Chevron USA v Natural Resources Defense Council, ${ }^{63}$ the Supreme Court seemed to defer completely to agency expertise. No such dramatic pair of opposing decisions exist in the ECJ's Article 190 jurisprudence, but two relatively recent cases do seem to point in quite different directions.

Re Agricultural Hormones: United Kingdom $v$ Council ${ }^{64}$ is a case in which the ECJ seems to take an extremely cavalier attitude to the giving reasons requirement. A Council directive failed to make any precise identification of the Commission proposal providing one of the reasons for its enactment. The ECJ holds:

The applicant's third complaint with regard to the statement of reasons is that the directive fails to identify the Commission's proposal. ... It must be observed ... that the directive in question does not in fact contain a precise reference enabling the Commission's proposal to be identified. However, that omission cannot be regarded as constituting an infringement of an essential procedural requirement, inasmuch as it is not denied that the directive was in fact adopted pursuant to a proposal from the Commission. ${ }^{65}$

Accepted at face value, this passage says that so long as a Community organ in fact had a reason, it was under no obligation to say what the reason was. Such a position by the ECJ would nullify even the minimum transparency requirement of Article 190.

Agricultural Hormones is one of those cases in which one is sorely tempted to guess at the identity of the opinion writer. The opinion is very much in the traditional French style-cryptic, conclusory, and inexplicable in its own terms. One resorts then to the normal technique of dealing with French judicial opinions, moving from the opinion itself to the surrounding paraphernalia. Advocate General Lenz's opinion informs us that this case is one of the special category, in which a Member State pleads Article 190 against a Council directive. In spite of the absence of a formal statement of reasons in the directives' preamble, the Member State must have been made fully aware of the Council's reasons in the course of its own direct participation in the Council's decision. Thus, while a

\footnotetext{
${ }^{83}$ Cheuron USA v Natural Resources Defense Council, 467 US 837 (1984).

64 Case 68/86, Re Agricultural Hormones: United Kingdom v Council, 1988 ECR 855, 1988:2 CMLR 543.

os Id, $1988 \mathrm{ECR}$ at $899,1988: 2$ CMLR at 573.
} 
formal statement of reasons would be preferable, the Member State has not been deprived of an essential procedural requirement because it had other means of knowing the Council's reasons.

In contrast, Regina v H.M. Commissioners of Customs and Excise ex parte the National Dried Fruit Trade Association ${ }^{88}$ shows a court inclined to move in the direction of D.C. Circuit techniques. The case deals with Commission regulations of general application roughly comparable to American "informal rules." The complaining party clearly seeks to push the ECJ from its normal requirement of something like an old-style concise and general statement of basis and purpose to the more detailed requirement of "reasoned elaboration." Advocate General Slynn is clearly somewhat tempted: "I think the reasoning can be criticized for not making more explicit the Commission's reasons for applying the protective measures to other kinds of dried grapes not produced in the Community." ${ }^{87}$ Yet, in the end, Mr. Slynn opts for a rather minimal giving reasons standard very close to the APA's concise and general statement of basis and purpose. He says Article 190 is satisfied because " $t]$ he overall purpose and intention [are] clear." "88

When the D.C. Circuit was transforming the "concise and general" and "arbitrary and capricious" wording of the APA into an aggressive substantive review standard, one of its major tactics was to shove the actual statutory language into footnotes and use expressions of its own coining like "reasoned elaboration." In $\mathrm{Na}$ tional Dried Fruit, the ECJ's judgment does not specifically invoke Article 190 itself or its own previous Article 190 formulae. Instead, the court says only that "the Commission's view . . . is sufficiently reasoned and is not to be regarded as incorrect." ${ }^{89}$ Having said this, the ECJ nonetheless goes on to invalidate one of the regulations at issue on proportionality grounds and to uphold two others. The ECJ's discussion is cast in purely substantive economic analysis terms, and it lumps together proportionality and reasons giving requirements in part of its analysis. ${ }^{70}$ In the end, the court upholds two Community regulations that it says make sense and strikes down one that does not.

(6) Case 77/86, Regina v H.M. Commissioners of Customs and Excise ex parte The National Dried Fruit Trade Association, 1988 ECR 757, 1988:2 CMLR 195.

${ }^{67}$ Id, 1988 ECR at 778, 1988:2 CMLR at 206.

${ }_{68}$ Id.

69 Id, 1988 ECR at 787, 1988:2 CMLR at 212.

${ }^{70}$ Case 77/86, National Dried Fruit, 1988 ECR at 790-91, 1988:2 CMLR at 214-216. 
Proportionality, like "least means" analysis, is obviously the strongest form of substantive review. In effect, courts are saying "We invalidate the law you have made because we can think of a better law-one that achieves your goals at less cost to competing interests." We should not make too much of National Dried Fruit, but it does show the potential that giving reasons exhibits for movement into substantive judicial review.

Agricola Commerciale Olio Srl v Commission ${ }^{71}$ has some curious resonances with National Dried Fruit. The Advocate General proceeds carefully and methodically, treating détournement de pouvoir, lawfulness, and factual error as substantive questions and breaking out Article 190 issues as separate and procedural questions. The ECJ does not explicitly mention Article 190 at all. The court's opinion marches through the Commission's decision, finding that "the only reason given" and "the only ground relied upon . . . is vitiated by errors of fact." 2 Taking the narrowest view, this case could be one in which the ECJ finds that the Commission has made an error of fact, thus falling afoul of a purely substantive non-giving reasons aspect of review. Having invalidated the Commission decision on this ground, the ECJ need not reach the Article 190 giving reasons issue. In the actual opinion, however, giving reasons, giving good reasons, and reasonableness are conflated as they so often are in American law.

\section{Conclusion}

The American experience from the 1960s onward gives us a number of hints as to what to watch for in the Community's giving reasons jurisprudence. We can see that an American-style dialogue requirement is being pushed hard by complaining parties who keep insisting that if a Community organ has not responded to all the points they have raised, Article 190 has not been satisfied. So far the ECJ has explicitly and repeatedly rejected the claim that Community organs must respond to all issues raised in the course of regulatory proceedings. At the same time, however, the ECJ has often answered claims that Community organs did not respond, not by saying simply that they had no obligation to respond, but by showing that they did actually respond. The more the ECJ answers Article 190 charges by itemized lists of responses made to

\footnotetext{
${ }^{71}$ Case 232/81, Agricola Commerciale Olio Srl v Commission, 1984 ECR 3881, 1987:1 CMLR 363.

${ }^{22}$ Id, 1984 ECR at $3898,1987: 1$ CMLR at 387.
} 
issues raised, the more it moves toward a dialogue requirement. It is one thing to reject an Article 190 claim on the grounds that no dialogue is required and quite another to reject a claim because the dialogue actually occurred.

Similarly, complaining parties have urged a synoptic standard under Article 190, requiring the Community organ both to give reasons for not having chosen the alternative policies it rejected and to give reasons for the one it selected. Here again the ECJ has rejected synoptic demands. Clearly such demands are hard to press on first order legislative bodies. How could we possibly ask Congress or the Council to give reasons for all the statutory provisions it rejected as well as for all those it enacted? It is easier to press synoptic demands on subordinate lawmakers enacting supplementary legislation within the narrow range of alternatives established by the primary statute. Here cases like National Dried Fruit are suggestive. Mixing reason giving and proportionality does yield something like synopticism. The supplementary lawmaker must give reasons why the regulatory alternative selected was chosen over other alternatives that would appear to achieve the statutory purpose less intrusively.

Finally, when considering Article 190 issues, the ECJ often moves to legislative-style analysis. The court looks not only to the purely procedural question of whether reasons are given but also to the substantive question of whether the reasons are good, correct, persuasive, or make sense. If the ECJ seeks to maintain fairly aggressive review, while at the same time avoiding a challenge to the expertise of its coequal branches, then Article 190 could provide a convenient half-way house. Many courts have found that telling an expert that they can not do something until they provide a better reason is easier than flatly rebuffing the expert.

Whether or not Article 190 develops in the way due process and the cursory APA requirements for informal rulemaking have developed depends then on how large a role the ECJ wants to play in assuring that Community primary and supplementary laws are reasonable. 1992 initiates rapidly accelerating Community-wide legislation and regulation. Thus, more aggressive substantive review is possible. What happens to Article 190 will depend on the temper of the times and the temper of the judges.

As to the judges, I am in no position to speculate. ${ }^{73}$ As to the times, developments are occurring that suggest a more expansive

${ }^{73}$ After this Article had been written, two new and as yet unpublished decisions have appeared that would suggest that the judges are moving in the directions indicated here. 
reading of Article 190, at least for purposes of achieving greater transparency. When European regulation of business was national, it could be and was done by direct and intimate communication between French, Dutch, or Danish bureaucrats and business executives who spoke the same language-both literally and figuratively. They had been to the same schools, lived in the same neighborhoods and often had worked in the same government offices together in their youth. Intimacy, not transparency, was the preferred style. Indeed transparency was shunned, because it would have allowed meddlesome outsiders into the tight little island of the regulators and regulatees. Now more and more regulation is done not at home, but in Brussels. I do not wish to exaggerate the change. The Brussels bureaucracy is drawn from the national bureaucracies and shares their taste for intimacy. Moreover, the French, Dutch or Danish business executive can still usually find some sympathetic compatriot and old friend somewhere in the Brussels establishment.

However, regulation is now one step removed and the old intimacy of direct dealings between government and business rendered somewhat reduced. The growth of a huge lobbying industry in Brussels represents one manifestation of this change: professional go-betweens are now necessary where at home they were

Both opinions repeat the standard formula that the Commission need not respond to every issue raised by the parties but must give sufficient reasons to enable the ECJ to exercise its power of review and the parties to decide whether to seek review. Nevertheless, both seem to demand a far more extensive Commission reasoned elaboration than Community judges had previously required. In Case 269/90, Technische Universitat Munchen v Hauptzollamt Munchen-Mitee (21 November 1991), Advocate General Jacobs admits that

[A]t present the case-law of the Court is . . . perfectly clear . . . [that] . . . a statement of reasons similar to the one contained [here], though laconic, was sufficient to comply with the minimum requirements of Article $190 \ldots$. Notwithstanding the above case-law, I question whether the minimum reasoning used by the Commission in such cases... satisfies the requirements of Article 190....

Id, p 25 of preliminary photocopied version. The ECJ found the Commission's statement of reasons insufficient to satisfy the demands of Article 190. Id, p 11, I 27 of the French translation of the preliminary photocopied version.

The second case, La Cinq SA v Commission, T-44/90, 24 January 1992 (preliminary original French text), is a decision of the Court of First Instance. Although in form rejecting a giving reasons challenge to a Commission ruling, the court holds that the Commission failed to examine important facts and so has "failed its legal obligation to take into account all the elements pertinent to the case." Id, p 32, I 94, author's translation. Most significantly for our purposes, in reaching this conclusion, the court stresses that the complaining party has repeatedly raised decisive points which the Commission has failed to address in its decision. Id, pp 30-32, 11 88, 91, 92 (I am indebted to Judge Koen Lenaerts of the Court of First Instance of the European Communities for pointing these cases out to me and providing me with the preliminary xeroxes. Of course he bears no responsibility for my interpretation of the cases). 
not. In these circumstances transparency begins to appear attractive to the regulated, who sometimes see themselves on the outside looking in, rather than on the inside and delighted to keep others out. Lately, Europeans have shown a strange interest in the Administrative Procedures Act, in "independent regulatory commissions" and in other American paraphernalia. ${ }^{74}$ At the same time, many Americans, tired of "adversary legalism," are yearning for a touch of the European style.

Giving reasons requirements are an obvious vehicle for transparency. Judicially enforced demands for transparency have a strong potential for translating themselves into vigorous, substantive judicial review of bureaucratic decisionmaking. Given the feelings of the times, this is a good time to start a fever charge for Article 190, one of the world's central devices for judicial enforcement of bureaucratic transparency.

${ }^{74}$ Furthermore, events in Eastern Europe show the yearning for transparency. 